\title{
Çocuk edebiyatında antiotoriter anlatım: Aytül Akal'ın “Güzel Kitaplarım” öyküsü
}

\section{Hatice FIRAT1}

\begin{abstract}
APA: Firat, H. (2020). Çocuk edebiyatında antiotoriter anlatım: Aytül Akal'ın "Güzel Kitaplarım" öyküsü. RumeliDE Dil ve Edebiyat Araştırmaları Dergisi, (19), 177-191. DOI: 10.29000/rumelide.752243.
\end{abstract}

$\ddot{O} \mathbf{z}$

Çocuk edebiyatı metinlerinde aranan temel özelliklerden biri olan "antiotoriter anlatım" kavramı, kitabın anlatımına egemen olan yaklaşımı, olayların farklı bakış açılarıyla sorgulanmasına izin veren anlatım biçimini ifade eder. Çalışmada, çocuk edebiyatının temel ilkelerinden olan antiotoriter anlatım özelliği temel ölçüt olarak alınmış, metinden verilen örneklerle bu özelliği ortaya koymak amaçlanmıştır. Çocuk edebiyatı metinlerinde antiotoriter anlatım özelliğine dayanan çalışmaların sınırlı olması sebebiyle çalışmanın alana katkı sağlayacağı düşünülmektedir. Araştırmada, nitel araştırma yöntemlerinden doküman incelemesi kullanılmıştır. Bu yöntem, araştırılması hedeflenen olgu veya olgular hakkında bilgi içeren yazılı materyallerin analizini kapsar ( Yıldırım ve Şimşek, 2008: 187). Çalışmada, Türk çocuk edebiyatının önemli yazarlarından olan Aytül Akal'ın "Güzel Kitaplarım” adlı öyküsü, doküman olarak incelenmiş; veriler betimsel analizle elde edilmiştir. Metnin özelliğini yansıtmak için doğrudan alıntılara yer verilerek elde edilen bulgular yorumlanmıştır. Çalışmada, incelenen eserin görselinde ve içeriğinde "otoriter" tavra sahip kahramanların ve otoriteyi/baskıcı tutumu örnekleyen olayların yer aldığı buna karşın yazarın anlatımında "otoriter" bir tavrın olmadığı belirlenmiştir. Yazarın eserde, çocukları olumlu tutum ve davranış değişikliğine yönlendirebilecek, onlara değer kazandırabilecek, yaşantılarında karşılaşabilecekleri birtakım durumlar için ön yargılarını kırabilecek olay ve durumlara yer verdiği görülmüştür. Yazarın “antiotoriter anlatım” özelliğine uygun olarak okura açıkça mesaj vermediği, yönlendirmede bulunmadığı, okuru farklı örnekler ve kişilerle karşılaştırarak onların konu üzerinde düşünmelerini sağlayabilecek bir anlatım gerçekleştirdiği belirlenmiştir. Yazar, didaktik bir anlatım yerine, okuru düşündürmeyi, doğruya yanlışa kendilerinin karar vermesini sağlayan bir anlayışla hareket etmiştir. Tüm bu verilere bağlı olarak çalışmada, metnin otoriter bir anlayışla yazılmadığı, yazarın antiotoriter yaklaşımı benimsediği sonucuna varılmıştır. Ayrıca bu durum; otoriter üslup kullanmadan da okuru bazı konularda düşündürmenin, değer, tutum ve davranış kazandırmanın (yani çocuk kitaplarında eğitselliğin) mümkün olduğu sonucunu ortaya koymaktadır.

Anahtar kelimeler: Antiotoriter anlatım, çocuk edebiyatı, Aytül Akal

\section{Antiauthoritative expression in children's literature: Aytül Akal's “Güzel Kitaplarım (My Beautiful Books)" story}

\begin{abstract}
The concept of "antiotoritarian expression", which is one of the basic features sought in the texts of children's literature, expresses the approach that dominates the narration of the book and the form of expression that allows events to be questioned from different perspectives. In the study, the

1 Doç. Dr., Muğla Sttkı Koçman Üniversitesi, Eğitim Fakültesi, Türkçe ve Sosyal Bilimler Eğitimi Bölümü, Türkçe Eğitimi ABD (Muğla, Türkiye), haticefirat@mu.edu.tr, ORCID ID: 0000-0001-8300-5189 [Makale kayıt tarihi: 30.04.2020kabul tarihi: 20.06.2020; DOI: 10.29000/rumelide.752243]


Antiauthoritative expression in children's literature: Aytül Akal's “Güzel Kitaplarım (My Beautiful Books)” story / H. Firat (pp. 177-191)

\begin{abstract}
feature of authoritative expression, which is one of the basic principles of children's literature, was taken as the basic criterion and it was aimed to reveal this feature with the examples given from the text. It is thought that the study will contribute to the field due to the limited number of studies based on antiotoric expression in children's literature texts. In the research, document review, one of the qualitative research methods, was used. This method involves the analysis of written materials that contain information about the phenomenon or facts intended to be investigated. In the study, Aytül Akal, who is one of the important writers of the field of children's literature, was named as "My Beautiful Books" data were obtained by descriptive analysis. Findings obtained by including direct quotations were interpreted to reflect the characteristics of the text. In the study, however, it was determined that there were no "authoritative" attitudes in the narrative of the author. It is seen in the work that there are events and situations that can lead children to a positive attitude and behavior change, add value to them, and break their prejudices for a number of situations they may encounter in their lives. It has been determined that the author did not expressly convey messages to the reader in accordance with the "authoritative expression" feature, did not provide guidance, and made a narrative that could enable the reader to think about the subject by comparing them with different examples and individuals. The writer acted with an understanding that allowed the reader to make a decision, to make the decision wrong, instead of a narrative expression. Based on all these data, it was concluded that the text was not written with an authoritative approach, and that the author adopted an anti-authoritative approach. Also this situation; reveals the conclusion that it is possible to make the reader think about some issues, to gain value, attitude and behavior (i.e. educational in children's books) without using authoritative style.
\end{abstract}

Keywords: Antiauthoritative expression, children's literature, Aytül Akal

\title{
1. Giriş
}

Çocuk edebiyatı metinlerinde aranan temel özelliklerden biri olan "antiotoriter anlatım", kitabın anlatımına egemen olan yaklaşımı, olayların farklı bakış açılarıyla sorgulanmasına izin veren anlatım biçimini ifade eden bir kavramdır (Dilidüzgün, 2013: 46). Buna bağlı olarak antiotoriter anlatım, yazarın üslubuyla ilgili bir terimdir ve yazar ile okur arasında iletişimi sağlayan metinde, yazarın okurunu "itaate, kabul etmeye" zorlayan otoriter bir tavra değil demokratik bir yaklaşıma sahip olduğunu anlatır.

Çocukların okumayı sevmesi, alışkanlığa dönüştürmesi ve okuma kültürü edinebilmesi için; öncelikle okuduğu kitap üzerinde düşünebilmesi, konuyu kendi duygu ve düşünce dünyası çevresinde değerlendirebilmesi ve kendi değer yargıları etrafında bir sonuca, kendi doğrularına varabilmesi gereklidir: "Çocuk bularak (keşfederek), girişimciliğini kullanarak doğruya ulaşmaktan hoşlantr. Çocuk kitabı yazarı, çocuk gerçekliğini de göz önünde bulunduran bir anlayışla çocuğu, anlamın oluşmasina ortak edebilmelidir.” (Sever, 2015: 38).

Antiotoriter anlatım özelliği taşıyan metinler, yazar ile okur arasında duygu düşünce aktarımının oluşmasına izin verir, okurun metni sorgulamasına, eleştirel bir okuma gerçekleştirmesine, eleştirel düşünmesine zemin hazırlar, okuru zihinsel olarak aktif tutar. Yazar doğrudan bilgi veren bir öğretici değil; yardımcı, yol göstericidir. 
Nitelikli çocuk edebiyatı eserlerinde eleştirel ve özgür düşünme ortamı sağlanmadan; düşünce üreten, tartışan, düşüncesini savunabilen, duygu ve düşüncelerini doğru ve etkili şekilde ifade edebilen, aktif okurlar yetişmesi mümkün değildir. Bu bakımdan antiotoriter anlatım niteliği, çocuk edebiyatı eserlerinde aranan temel bir özelliktir: "Çocuk edebiyat, anlamadan, sorgulamadan karar veren insanlar yerine; düşünerek, duyumsayarak karar verebilecek duyarl insanlarm yetiştirilmesine dönük bir çabanın ürünü olarak adlandırlabilir. (Sever, 2003: 16).

\begin{abstract}
...türü ne olursa olsun, duyma ve düşünme sorumluluğunu okura birakan; öğrencinin yorumlamasına, kestirimde bulunmasına, değerlendirme ve yorumlar yapmasına ve yaşamla ilişki kurmasına, metindeki olaylar üzerinde kendi kararlarını verebilmesine olanak sağlayacak metinlerin seçilmesi çok önemlidir. (Aslan, 2017: 209).
\end{abstract}

Toplumsal yaşam içerisinde evde anne-babasının, okulda öğretmeninin, yakın çevrede arkadaşlarının baskısı altında kalabilen çocuklar; edebiyat ortamında da yazarın baskısı altında kalabilmektedir. Yazar metninde okur üzerinde baskı kurmuşsa (kendi doğru ya da yanlışlarını mesaj olarak veriyor ve bunu kabul ettirmeye çalışıyorsa) otoriter bir yaklaşımı benimsemiş demektir.

Yazarın kendi görüşünü ve eleştirisini okuruna zorla benimsetecek derecede olayları tek yanlı sunması, anlatımında duygusal ve retorik efektler kullanarak kitabın vardığı sondan başka olasılığa yer vermemek, otoriter anlatımın göstergelerindendir. (Dilidüzgün, 1996: 80).

Fatih Erdoğan (2019: 99) çocuk edebiyatı ürünlerinde mesajın; bir uyarı, bir öğüt, bir önerme, bir yönlendirme olabileceğini belirtir. Ayrıca çocuk kitaplarında mesaj konusunu açıklarken "çocuklara yönelik kitaplarda bu daha çok anne babanın 'şimdi çocuğum bu kitabr okuyunca ne öğrenecek?' sorusunun cevabıdır. 'Anafikir' ile aym ailedendir ancak daha çok bir slogan cümlesi beklentisi akla getirir.” diyerek mesaja dayanan, yazarı otoriter anlatımı benimsemiş metinlerin özelliklerini vurgular. Çocuklar için yazılan eserlerde yazarların otoriter anlatıma sahip olması, okurları okuma eyleminden ve kitaplardan soğutabilecek bir özelliktir.

"Çocuk yazınında eğitsellikten uzak durmakta yarar var. ... Çocuk kendisine öğüt verildiğini anladığında, kitaptan kaçıyor. ... Çocuğun kendini kitabı okumaya kaptırdığı bir anda, ona öğüt vermek başına balyoz gibi inebilir.” (Canlı, Doğan Güldenoğlu, İnce Samur, 2016: 101).

Yıldız, Ketenoğlu Kayabaşı, Ayaz ve Aklar (2017; 517)'ın çocukların kitap sevmeme nedenlerini araştırdıkları çalışmada, çocukların kitap okumayı sevebilmeleri için sundukları öneriler aralarında "kendi istedikleri kitapları okumak ve üzerlerinde baskı olmaması" talebi dikkat çekicidir. Buradan aile ya da öğretmenin baskısının çocukları kitaptan uzaklaştırdığı sonucu çıkmaktadır. Aynı şekilde çocuk kitaplarında yazarın bir ebeveyn (anne-baba) ya da öğretmen gibi davranması, nasihatçi tutumu benimsemesi de çocuklar üzerinde baskı oluşturmakta, çocuğu kitaptan uzaklaştırmaktadır. Bu anlamda yukarıda bahsi geçen araştırmada çocukların verdiği cevaplar; baskıdan, otoriteden hoşlanmadıklarını ve bunun onları okuma eyleminden uzaklaştırdığını göstermesi bakımından önemlidir. Bu durum çocuk edebiyatı ürünlerinde otoriter anlatımdan uzak durulması gerektiği fikrini desteklemektedir.

Lukens, Smith ve Miller Coffel'a göre, edebiyatın doğrudan insanları doğru davranışlara sevk etmek, rehberlik etmek gibi bir işlevi söz konusu değildir. Bu işlevin yani didaktik yaklaşımın/öğüt vermenin ders kitaplarından beklendiğini belirterek çocuk kitaplarında öğretme ve ahlaki ders verme eğiliminden uzak durulması gerektiğini vurgularlar:

"Çoğu zaman çocuklara ne yapmaları veya yapmamaları gerektiğini söyleyerek onlara yardımcı olmayı diler, bunu sık sık sloganı andıran öz ifadelerle veya kısa nutuklar halinde yaparız. Kendi 
Antiauthoritative expression in children's literature: Aytül Akal's “Güzel Kitaplarım (My Beautiful Books)” story / H. Frrat (pp. 177-191)

geçmiş deneyimlerimizi temel alarak, onlara aslında anı anlatma kisvesi altında talimat veren öyküler anlatırız. Kimi zaman da daha karmaşı öyküleri tek bir mesaja, genellikle onların duymasını istediğimiz bir mesaja indirgeriz. Çocuklar, tıpkı yetişkinler gibi düşünmek için fırsat verilmesini arzu ederler. Eserde bulunacak kuvvetli bir mesaj varsa bile ton, öğretmeye veya ahlak dersi vermeye aşırı meyilli olmaktan kaçmalıdır.” (2018: 2, 233, 250)

Sever (2003: 132) de edebi nitelik taşıyan metinlerin asıl amacının çocukların sezme, duyma, düşünme yetilerini geliştirmek, onlara insana özgü duyarlık kazandırmak olduğunu, bilgi verme amacının ise öğretici metinlere ait olduğunu belirtir. Erdoğan (2019: 100, 102) da kitapların hem eğitim alanı için en uygun araçlardan biri, hem de sanatsal bir haz alma aracı olduğunu ancak sanatsal bir haz alma aracı olma niteliğinin daha önde geldiğini vurgular. Ayrıca, Türkiye'de çocuk edebiyatının bir sanat olarak gelişmemesinin en büyük nedeninin kitapların "ders aracı" olarak algllanmasından kaynaklandığını ifade eder.

Bir edebi metnin temel vasfı estetik olmak, okura zevk vermek olarak görülse de henüz öğrenme çağında olan insanlar/çocuklar söz konusu olduğunda edebi eserden okuruna faydalı olması da beklenen bir durumdur. Edebi eser öğretici/nasihatçi bir üsluba sahip olmadan da okurunu yönlendirerek onun konu üzerinde düşünmesini, doğruyu-yanlışı keşfetmesini sağlayabilir.

... çoğu çocuk kitabının içindeki öğreticiliği bizler dayatmacı olduğu için eleştirmekteyiz. Aslında verilmesi gerekeni okur olan çocukla birlikte tartışarak çıkartan bir kitabın sergilediği öğreticilik hiç de olumsuz karşllanmaz. (Dilidüzgün, 2007: 142).

Sanatçı, ... Vereceği dersi yasa maddeleri ya da ders notları ezberletir gibi kuru kuruya değil, sezgi, yaşantı ve telkin yoluyla, estetik yolla verir. Bu yönüyle sanat, genel anlamda eğitimin bir organı ve aracıdır. (Kavcar, 1999: 2-3).

Genel olarak antiotoriter anlatımla ilgili değerlendirmeler ele alındığında, bir eserde antiotoriter anlatımın benimsendiğini gösteren temel özelliklerin yazarın;

- Açıkça mesaj vermemesi, öğretici-nasihatçi bir anlayışa, taraflı bir tutuma sahip olmaması,

- Sezdirici, keşfettirici bir yaklaşımı benimsemesi,

- Yukarıdaki maddelere bağlı olarak doğruyu-yanlışı doğrudan söylemek yerine anlatılan olay ve durumlar üzerinden çocuğun sorgulamasını sağlayacak bir anlatımı gerçekleştirmesi (okurun düşünmesine, tartışmasına, kendi düşünceleri doğrultusunda sonuca varmasına imkân vermesi),

(Tüm bunların göstergesi olarak) metinde;

- Demokratik bir ortamın oluşturulması,

- Tek anlamlılık değil çok anlamlılık özelliğinin sağlanması,

- Eserin ana fikri olarak değerlendirilebilecek ifadelere yer verilmemesi,

- Otoriter anlatımlı metinlerde olduğu gibi slogana bezeyen cümlelerin kullanılmaması,

- Okurun yapması ya da yapmaması gerekenleri belirten emir ve gereklilik ifadelerinin/cümlelerinin yer almaması vb. olduğu söylenebilir.

Bu noktadan hareketle çalışmada, çocuk edebiyatının temel ilkelerinden biri olan antiotoriter anlatım özelliği ölçüt olarak ele alınmış, Aytül Akal’ın “Güzel Kitaplarım” öyküsü bu özellik açısından 
incelenmiştir. Araştırmada, antiotoriter anlatım kavramını metinden örnekler vererek açıklamak ve bu özelliği taşıyan metinlerin niteliklerini ortaya koymak amaçlanmaktadır. Çocuk edebiyatı metinlerinde antiotoriter anlatım özelliğini ortaya koyan çalışmaların sınırlı olması sebebiyle bu çalışmanın alana katkı sağlayacağı düşünülmektedir.

\section{Yöntem}

Çalışmada, nitel araştırma yöntemlerinden doküman incelemesi kullanılmıştır. Doküman incelemesi, araştırılması hedeflenen olgu veya olgular hakkında bilgi içeren yazılı materyallerin analizini kapsar. Bu tür araştırmalarda araştırmacı ihtiyacı olan veriyi gözlem veya görüşme yapmaya gerek kalmadan elde edebilmektedir. (Yıldırım ve Şimşek, 2008, s. 187). Araştırmada çocuk edebiyatı metinlerinde aranan temel özelliklerden biri olan antiotoriter anlatım özelliği temel ölçüt olarak ele alınmış ve çalışmada çocuklar için yazılan öykü metinlerinden Aytül Akal'a ait "Güzel Kitaplarım” adlı eser doküman olarak incelenmiştir. Çalışmanın verileri betimsel analiz ile elde edilmiştir.

Araştırmada, antiotoriter anlatımın karşıtı olan otoriter anlatımın temel nitelikleri de belirlenerek dikkate alınmış ve buna bağlı olarak bir eserde antiotoriter anlatımın benimsendiğine işaret eden özellikler (eserin ana fikri olarak değerlendirilebilecek ifadelere yer verilmemesi, öğretici ve taraflı bir tutumun benimsenmemesi, metnin tek anlamlı değil çok anlamlı olması, slogana bezeyen cümlelerin kullanılmaması, okurun yapması ya da yapmaması gerekenleri belirten emir ve gereklilik ifadelerine/cümlelerine yer verilmemesi ve buna bağlı olarak demokratik bir ortamın oluşturulması) saptanmıştır. "Güzel Kitaplarım" adlı öykü, bu özellikler dikkate alınarak analiz edilmiştir. Metnin özelliğini yansıtmak için doğrudan alıntılara yer verilmiş, elde edilen bulgular yorumlanmıştır

\section{Bulgular}

"Güzel Kitaplarım” adlı öykü, antiotoriter anlatım özelliği açısından incelenmiş ve çalışmada elde edilen bulgular "Öykü görseline ilişkin bulgular" ve "Metnin içeriğine ilişkin bulgular" olmak üzere iki başlık altında sunulmuştur.

\section{1. Öykü görseline ilişkin bulgular}

Otorite kavramına bağlı olarak öykünün başında yer alan resme bakıldığında "eserin anlatımında" otoritenin varlığına ya da yokluğuna ilişkin veri elde edilebilmesi mümkün değildir. Ancak kahramanların otoriter olup olmadıklarına ilişkin veriler elde edilebilmektedir. Çalışmada öykü görseli, eserin içeriğine ilişkin bir takım verileri sezdirmesi, olaya hazırlayıcı olması ve metnin içeriği öğrenildiğinde daha da anlam kazanması nedeniyle incelemeye dâhil edilmiştir. 


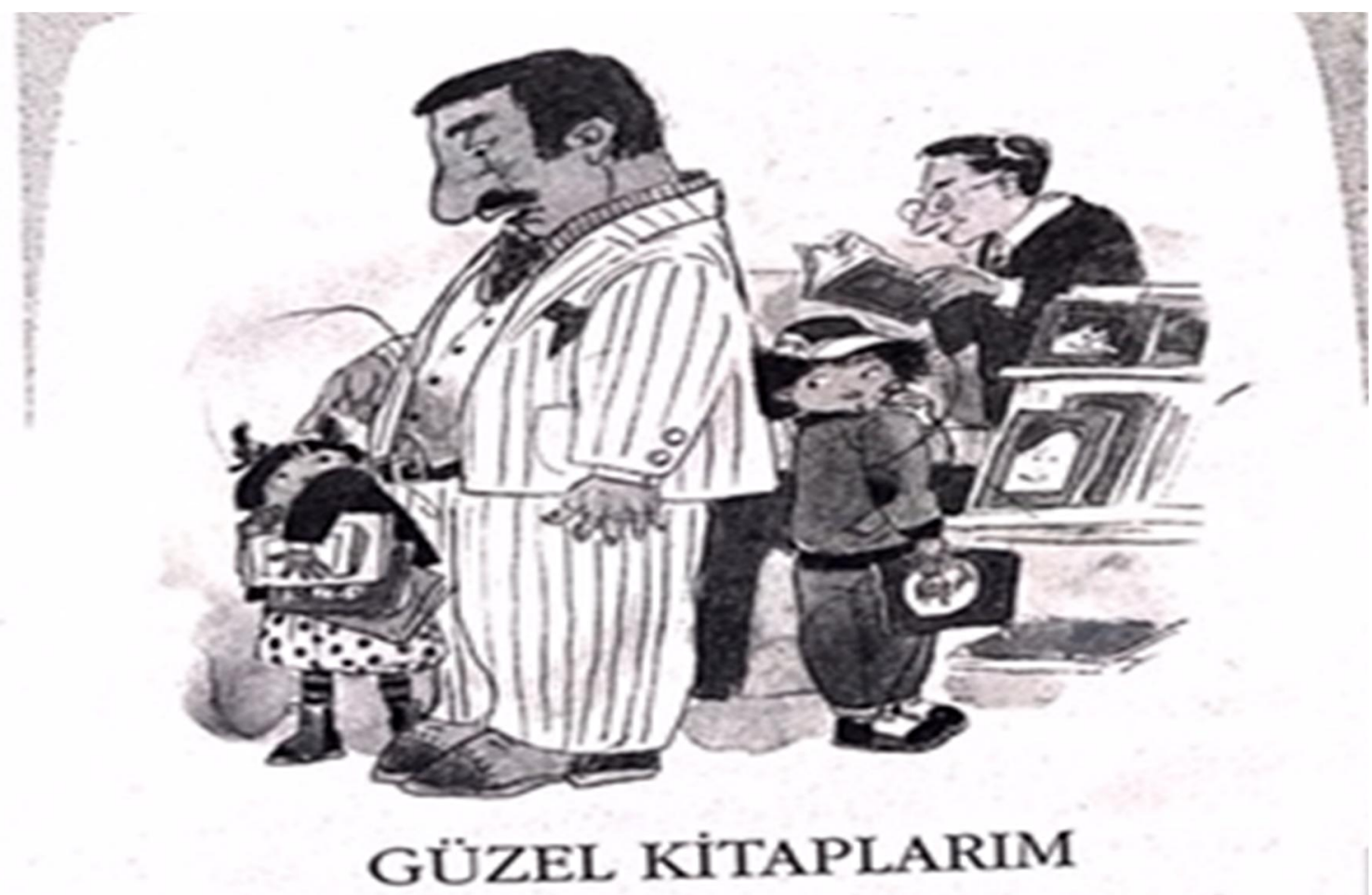

(Akal, 2003: 45)

Hikâyenin başlangıç kısmında eserin konusu, mekânı vb. hakkında fikir sahibi olunmasını sağlayan bir resim yer almaktadır. Bu resimde; önde çizgili takım elbise giymiş bir adam ve hemen önünde ondan korktuğu ve kitaplarına sarıldığı görülen bir kız çocuğu, arka tarafta onları izleyen ve şaşkınlıkla bakan bir çocuk, bu çocuğun ilerisinde kitap okuyan başka bir adam görülmektedir. Raflarda duran kitaplardan mekânın bir kitapçı olduğu sezilmektedir.

Önde bulunan kız çocuğunun kitaplarına sarılmış olması, onları çok sevdiğini ve sahip olmak istediğini anlatırken yukarıdan parmağını ona doğru uzatmış olan adamın bu noktada bir engel oluşturduğu/oluşturabileceği düşünülebilir. Çünkü adamın işaret parmağını çocuğa doğru uzatmış olması, bir uyarının hatta baskıcı bir tavrın söz konusu olduğunu hissettirmektedir. Aynı zamanda adam, çok ciddi ve sert bir görünüme sahiptir. 

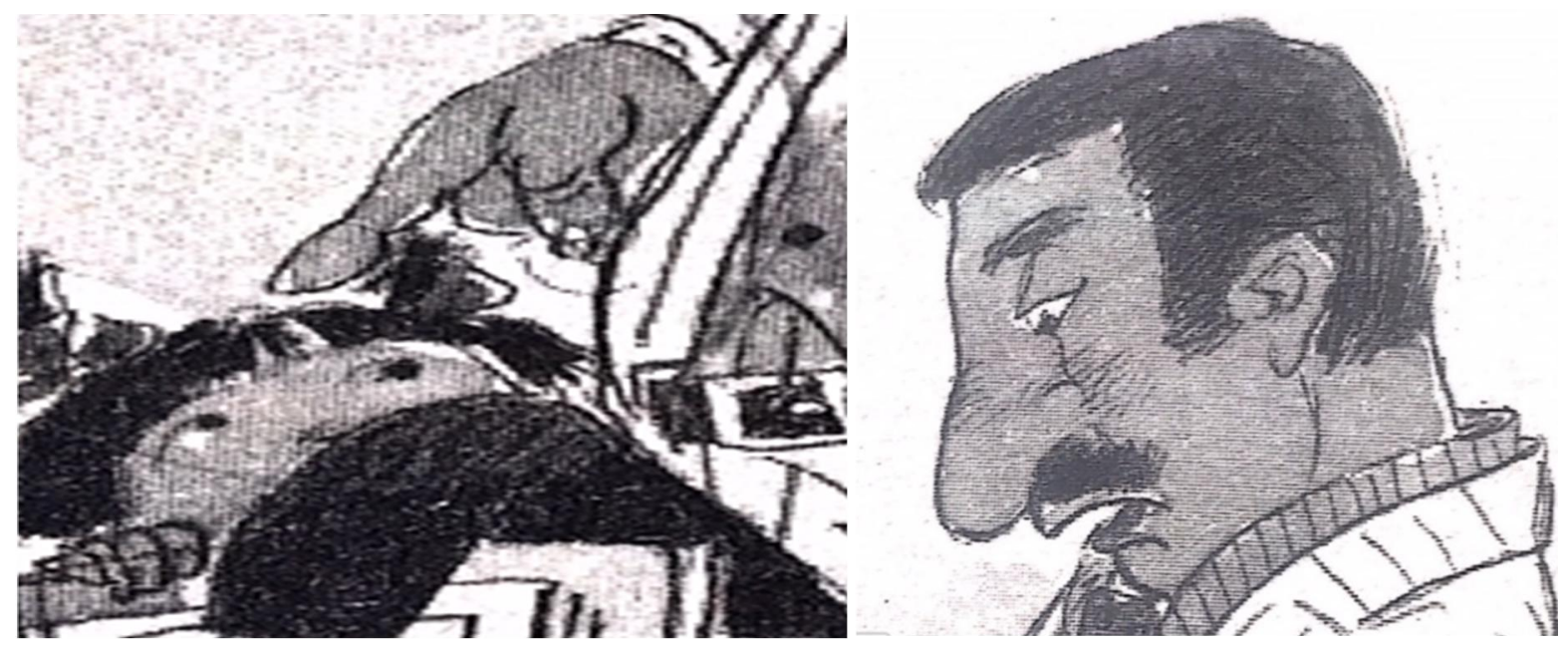

(Akal, 2003: 45)

Henüz kim olduğu bilinmeyen adamın işaret parmağının havada olması, öykünün baskıcı, karşısındakini itaat ettirme gücüne sahip vb. sıfatlarla ifade edilebilecek otoriter kişisi olduğunu sezdirir. Bu durumda küçük kız, baskı altındaki kişi olarak okur karşısına çıkmaktadır. Resimde kitapçıda bulunan herkes kitaplarla ilgilenirken parmak sallayan adamın elinde kitap olmaması, onun kitap okuma alışkanlığına sahip olmadığını da akla getirebilir.

Görselde arkada duran çocuğun elinde kitap, karşısında kitap rafı olması kitap okumayı sevdiğine işaret etmektedir. Bu çocuk, küçük kız çocuğu ile adam arasında yaşanan diyalogla yakından ilgilidir.

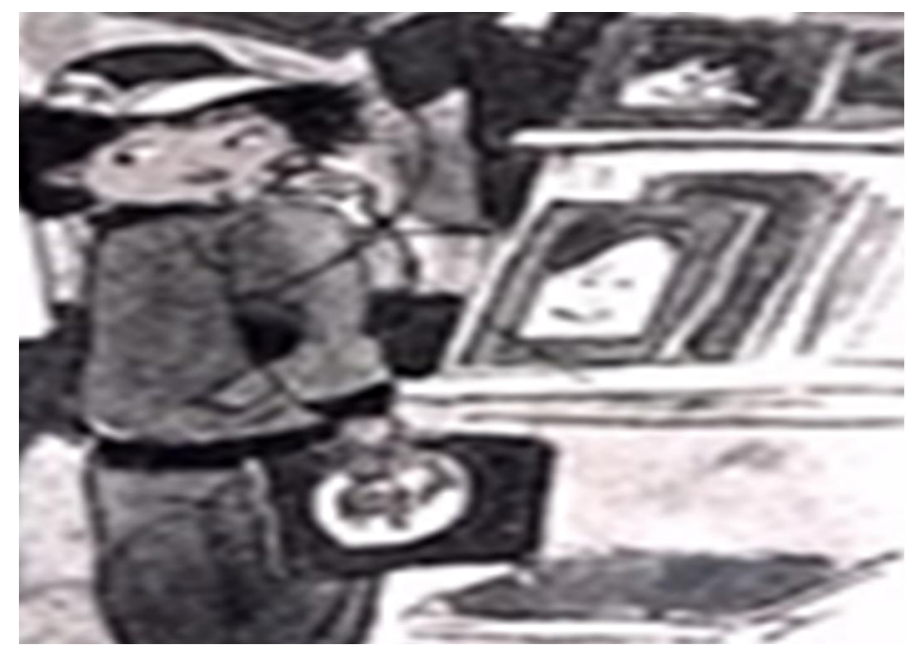

(Akal, 2003: 45)

Görselde arkada bulunan adam ise elindeki kitabı incelemekte ve önde yaşananlardan habersiz görünmektedir. Gülümsüyor olması, kitap okuyor olması gibi ayrıntılar okura diğer adamdan farklı özelliklere sahip olduğunu düşündürür. 


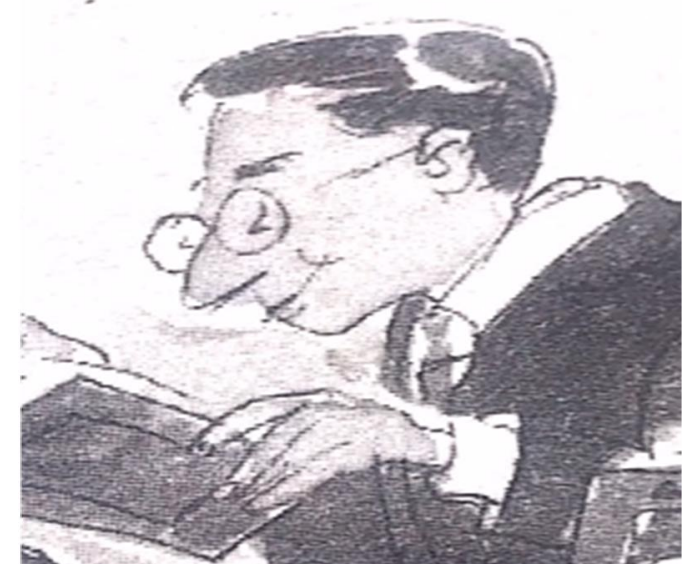

(Akal, 2003: 45)

\section{2. Öykünün içeriğine ilişkin bulgular}

Bu bölümde metnin içeriği bir eserde antiotoriter anlatımın benimsendiğini gösteren; "eserin ana fikri olarak değerlendirilebilecek ifadelere yer verilmemesi, öğretici ve taraflı bir tutumun benimsenmemesi, metnin çok anlamlı olması, slogana bezeyen cümlelerin kullanılmaması, okurun yapması ya da yapmaması gerekenleri belirten emir ve gereklilik ifadelerine/cümlelerine yer verilmemesi ve buna bağlı olarak demokratik bir ortamın oluşturulması" özellikleri dikkate alınarak incelenmiştir. Bu özelliklerin iç içe geçmiş olması, bir bütün olarak yer alması bakımından çalışmada ayrı ayrı başlıklar açılmamış, metin bütün olarak değerlendirilmiştir. Metinde anlatılanlarla öykü görseli arasında ilişki kurulmuş ve açıklanmıştır.

Öykünün giriş cümleleri, eserdeki anlatıcının resimde arkada duran çocuk olduğunu göstermekte ve resme bakarak tahmin edilen bazı noktaları doğrulamaktadır: "Hafta sonunda babamla birlikte kitapçıya gittik, kendimize kitap seçtik. Bir tane o ald, iki tane de ben.” (Akal, 2003: 45).

Mekân bir kitapçı, çocuk ve babası da kitap okumayı seven kişilerdir. Bu bilgiden arkada kitap okuyan kişinin rafın önündeki çocuğun babası olduğu da anlaşılmaktadır. Çocuk kasaya giderken küçük çocuklar için (okulöncesi dönem, ilkokulun ilk yılları) ayrılan bölüme gözü kayar, birinci sınıfa giderken okumayı öğrenemeyeceğini; küçük puntolu, az resimli kitapları hiç okumayacağını düşündüğü günleri hatırlar ve “... o günkü düşüncelerime artık gülüyorum” (Akal, 2003: 46) der.

Okula yeni başlayan pek çok çocuk okumayı öğrenememe korkusu ya da diğerlerine göre geç öğrenme stresi yaşayabilir. Çocuklar küçük yazılı, resmi az olan kitapları okumak istememe eğilimi gösterebilir ya da okuyamayacağını düşünebilir. Yıldız, Ketenoğlu Kayabaşı, Ayaz ve Aklar (2017; 513-514) tarafından gerçekleştirilen ve çocukların kitap okumayı sevmeme nedenlerinin araştırıldığı çalışmada kitapların sevilmeme nedenleri arasında "resimsiz olması, uzun yazılar olması ve yazıların küçük olması"; kitaplardan beklentileri arasında "az sayfalı, büyük yazıll, resimli” olma gibi özelliklerin öne çımış olması da bu durumu desteklemektedir.

Yazarın eserde, çocuk kahramanın yaşadığı bu duygu durumunu aktararak, kahramanı üzerinden okumayı yeni öğrenen çocukların konu üzerinde düşünmesini sağlamak istediği akla gelmektedir. Çocuk okurlar açısından bakıldığında eser, okumayı öğrenemeyeceği; küçük yazılı, az resimli kitapları okuyamayacağı gibi düşünleri olanlara, bu tür düşüncelere kapılmalarının normal olduğunu, pek çok 
çocuğun bu durumu yaşadığını göstermektedir. Buna göre metin, benzer sorunlar yaşayan çocuk okurun rahatlamasını, ön yargılarının ortadan kalkmasını sağlayabilecek bir yaklaşım içermektedir. Ayrıca kahramanın, bir zamanlar sahip olduğu bu düşüncelere artık güldüğünü söylemesi, bu durumun gelip geçici olduğunu, zamanla yaşanan gelişmeye bağlı olarak bu tür sorunların ortadan kalkacağını okura sezdirmektedir. "Sezdirmektedir" denmesinin nedeni, metinde bu düşünceleri ortaya koyacak herhangi bir ifadenin yer almamasıdır. Açıcça verilmiş herhangi bir mesaj/öğüt vb. bulunmamaktadır. Mesajın doğrudan verilmemesi, okurun düşünerek ulaşmasının sağlanması yazarın öğretici bir tutum yerine yol gösterici (keşfettirici, sezdirici) bir anlayışla hareket ettiğini ortaya koyar.

Metnin devamında anlatıcı olan çocuk, küçük çocuklar için ayrılan kitapların olduğu yere gelip "İşte, benim güzel kitaplarım...” (Akal, 2003: 46) diyerek okumayı öğrendiği resimli kitaplara karşı duyduğu sevgiyi dile getirir. Anlatıcı çocuk, güzel kitaplarına bakarken bu kitapların neredeyse hepsini okuduğunu, kiminin evdeki kitaplığında durduğunu (yani satın aldığını), kimini de arkadaşlarıyla değiş tokuş yaparak okuduğunu ifade eder. Bu bölümde yazar, çocuklara kitapların önemini, onları sevmek gerektiğini anlatmak yerine; çocuk okurları kitapları çok seven, çok kitap okuyan bir kahramanla karşlaştırmakta ve onların sezgilerini harekete geçirerek doğrudan mesaj vermek yerine söylenebilecek şeyleri kendilerinin hissetmelerini sağlamaktadır. Kahramanın okuduğu kitaplardan oluşan bir kitaplık oluşturması, çocuk okurlara örnek olması bakımından önemlidir. Çünkü çocukların okuma alışkanlığı, sevgisi kazanması ve okuma becerilerinin gelişmesinde "okuduğu kitaplardan bir kitaplık oluşturma, evde kendine ait bir kitaplığa sahip olma” (Nas, 1999: 190) gibi özellikler önemlidir.

Kitap okumanın bir eğitim etkinliği olarak işlevini sürdürebilmesi için evlerde ve okullarda zengin bir kitaplık oluşturmaya önem verilmelidir. (Durualp, Çiçekoğlu ve Durualp, 2013: 128).

... Evinde kitaplık olan öğrencilerin olmayan öğrencilere göre son olarak kendine ait kitaplı̆̆ olan öğrencilerin olmayan öğrencilere göre okuma alışkanlığına daha çok sahip olduğu şeklinde yorumlanabilir. ( Başaran ve Altuner, 2016: 587).

Yazar, çocuklara okudukları kitaplardan oluşan bir kitaplık oluşturmalarını söylemek yerine onları bunu gerçekleştirmiş bir kahramanla karşlaştırır. Böylece nasihat etmenin, doğruyu yanlışı söylemenin sıkıcılığını ortadan kaldırır, okuru gördüklerini yorumlayarak doğruya ulaşmaya sevk eder.

“Neredeyse raflardaki kitaplarn hepsini okumuşum... Kimi evde, kitaphğımda duruyor hâlâ. Kimini de, arkadaşlarımla değiş tokuş yaparak okudum...”(Akal, 2003: 46), ifadesi dikkate alındığında; ekonomik nedenlerle kitap alamayan, okuyamayan çocuk okurların eserde bu soruna bir çözüm bulmaları da mümkündür. Metnin anlatımından çıkan çözüm önerisi, arkadaşlar arasında kitap değiş tokuşu yaparak daha çok kitap okumaktır.

$\mathrm{Bu}$ çözüm önerisi kullanıldığı takdirde kitaplıklarda bulunan kitaplar raflarda tozlanmak, işlevini yerine getirmeden süs olarak kalmak yerine işe yarar hale gelecek ve pek çok kişiye ulaşacaktır. Ayrıca bu yolun kullanılması; paylaşmak, yardımlaşmak gibi evrensel değerlerin çocuklar tarafından kazanılması demektir. Buna karşın metinde bu değerlerden bahsedildiğini gösteren bir cümleye rastlanmamaktadır. Böylece yazar, metnin derin anlamında yer verdiği çözüm önerisini ve öne çıkardığı değerleri öğretici bir yaklaşımla dile getirmemiş, bunları yine okura düşündürerek buldurma yolunu seçmiş görünmektedir.

Eserin başkahramanı/başkişisi olan çocuk, çocuk kitaplarıyla ilgilenirken resimde ön tarafta bulunduğu görülen baba ve kızın konuşmalarına şahit olur. Baba biraz sinirli, sert bir yüz ifadesiyle 
Antiauthoritative expression in children's literature: Aytül Akal's “Güzel Kitaplarım (My Beautiful Books)” story / H. Firat (pp. 177-191)

kızına yaklaşır, kolundan çekiştirir ve artık kitaplarını bırakmasını ister. Babanın bu bölümde yapılan betimlemesi, onun otoriter bir yapısı olduğunu göstermektedir. Küçük kız ise kitapları bırakmak istemez. Baba, kızına bu kitapları okumayı öğrenince alabileceklerini söyler ancak kızı ısrarla hemen almak ister. Öğretmeninin kitap okumalarını istediğini belirtir. Çocuğun okuma bilmemesi ancak öğretmeninin olması gibi ipuçları, onun anasınıfı öğrencisi olduğuna/okulöncesi dönemde olduğuna işaret eder.

Okuma alışkanlığının temeli bedensel ve ruhsal gelişimlerin, değişmelerin yoğun biçimde yaşandığı çocukluk döneminde atılmaktadır. "Temeli çocukluk döneminde atılan alışkanlık gençlik döneminde zevk ve gereksinim olarak algılanarak alışkanlık haline dönüşmektedir. Genelde eğitim süreci, okul ve dolayısıyla bilgi ile yoğun ve sistematik bir ilişkinin kurulduğu bu dönemler okuma alışkanlığı için en uygun koşullarm bir araya geldiği bir süreç anlamina gelmektedir" (Yllmaz, Köse, Korkut, 2009: 23). Okuma kültürü edinme sürecinde erken çocukluktan başlayarak nitelikli kitaplarla etkileşim ve iletişim kurulması önemlidir. Bu nedenle bireylere okul öncesi dönemde "okuma sevgisi”, ilkokulda "okuma alışkanlığı" ve ortaokulda "okuma kültürü” kazandırılmalıdır. Okuma kültürü edindirmenin ilk basamă̆ ise "Okulöncesi dönem"dir (İnce Samur, 2016: 2-3, 6). Sever (2015: 95-96) de okulöncesi dönemde kitap sevgisi oluşturmaya yönelik çabaların, çocukların ilköğretim yıllarındaki okuma kültürünü büyük ölçüde etkilediğini belirterek, okulöncesinde çocukların kitapla buluşmasının önemini şu şekilde vurgular:

Okulöncesi dönemin ilk yllarında kitaplar, çocukların hem kavramsal gelişimi hem de oynama, eğlenme, bulma (keşfetme) gereksinimleri için çok uyaranlı bir ortamın oluşmasına katkı sağlar. Görsel ve dilsel özellikleriyle çocuğun yaşamla bağını kurar. Çocuğun ilgi ve beğeni alanına girerek onu eğlendirir. Her şeyden önemlisi de yarattığı çocuğa özgü kurgularla çocuk için doğal bir yaşantı edinme kaynağı olur.

$\mathrm{Bu}$ nedenle her ne kadar okuma becerisi ve alışkanlığı genel olarak ilkokul dönemi ve sonrasını kapsıyor görünse de ilkokul ve sonrasında okuma alışkanlığındaki gelişmenin üst düzeyde olması için okulöncesi dönem eğitimine önem verilmesi gerekmektedir (Çocuk Vakfı, 2006: 4, 6). Çocuklara kitap almaya başlamak için okumayı öğrenmelerini beklemek yanlıştır ve geç kalınmasına sebep olmaktadır.

Bu bilgiler dikkate alındığında, öyküdeki babanın “okumayı öğrenince kitap alınabileceği” düşüncesine sahip olması, onun okuma alışkanlığına ilişkin yeterli ve doğru bilgiye sahip olmadığını gösterir. Buna bağlı olarak da eserde okurun karşısına bu düşünceyle çıkan baba karakterinin doğru bir örnek olmadığı, düşüncelerinin doğruyu yansıtmadığı belirtilmelidir. Ancak eserde yazar tarafından bu duruma ilişkin herhangi bir yorum yapılmamış, yaşanan olaylar üzerinden bu babanın düşünce ve tavrının doğru ya da yanlış olduğunun değerlendirmesi yine okura bırakılmıştır. Babanın bu düşüncesine karşılık kız çocuğunun kitapları almak için ısrar etmesi babasının sert bir tepki vermesine sebep olur: "Adam, çocuğun koluyla göğsünün arasına sıkıştrrp bütün gücüyle korumaya çalsştığı kitapları iki eliyle hızla çekip aldı; raflarda dizili kitapların arasına firlatt..” (Akal, 2003: 47).

$\mathrm{Bu}$ davranışlar babanın demokratik bir anlayışa sahip olmadığını, kızının düşüncelerini önemsemediğini ve sadece kendi doğrusunu çocuğa kabul ettirmek istediğini gösterir. Babanın yaklaşımı ve "çekip almak, fırlatmak" gibi eylemleri onun otoriter bir tutum içerisinde olduğu düşüncesini desteklemektedir. Sevdiği kitapların alınıp fırlatılması çocuk üzerinde ciddi olumsuz etkileri olabilecek, duygusal şiddet olarak değerlendirilebilecek bir davranıştır. Dolayısıyla eserdeki kız çocuğunun, zaman içerisinde düşüncelerini rahatlıkla ifade eden, kendine güvenen bir insan olarak yetişmesi çok zor görünmektedir. Bu durum genel olarak "otorite" kavramının olumsuz bir anlama sahip olduğunu da göstermektedir. Bahsi geçen tüm bu özellikler otoriter bir yazar ve okuru arasındaki 
ilişki için de geçerli olan niteliklerdir. Bu otoriter baba ve kızı arasındaki yaşantının/ilişkinin nitelikleri otoriter bir yazar ve okuru arasındaki ilişkiyle benzerlik göstermesi açısından bu çalışma için önemlidir.

Buraya kadar anlatılanlara bakarak okur, babanın ekonomik nedenlerle kitap almak istememiş olabileceğini düşünebilir. Ancak sonrasında yaşanan olaylara bakıldığında nedenin ekonomik olmadığı anlaşılmaktadır: "-Şimdi boşa para harcatma bana. ... Gel en iyisi biz şuradan çıkp, yan taraftan içecek bir şeyler alalım. Kizarmış patates ve hamburgere ne dersin?” (Akal, 2003: 47).

Kızının ısrarına karşı babanın önerisi, asıl sorunu gösterir. Çünkü babanın kızına hamburger, patates kızartması gibi sağlığa zararlı yiyecekleri alabilecek parası bulunmakta; baba, bunlara harcanan parayı boşa harcanmış saymamakta buna karşın kitaba harcanan paranın boşa gittiğini düşünmektedir. Bu durum babanın hamburger ve patates kızartmasını kitaptan daha çok önemsediğini gösterir. Baba için yeme içme bir ihtiyaç, kitap ise temel bir ihtiyaç değildir. Kısacası okuma sevgisi ve alışkanlığı olmayan bir kişidir.

Yazarın anlatımı açısından bakıldığında, bu babanın taşıdığı özelliklere dair eserde yazar tarafından söylenmiş tek bir cümle bulunmamaktadır. Okur, babanın tavrı ve küçük kızın yaşadığı sıkıntıya bağlı olarak eserin kişileri hakkında bir değerlendirme yapacaktır. Böylece yazar bu tavırların yanlışlığını sorgulamayı doğrudan okuruna bırakmış, babanın tavırlarının yanlışlı̆̆ını söyleyen otoriter bir yazar olmaktan kurtulmuştur. Eserdeki bu aile değerlendirildiğinde; küçük kız, kitaplara ve okumaya duyduğu sevgiyle, kitaplarını korumaya çalışmasıyla, mağduriyetiyle okurun kendisine yakın hissedeceği kişi, babası ise okurun onaylamadı̆̆ı olumsuz özelliklere sahip kişi olarak öne çıkmaktadır.

Küçük kız ve babası arasında yaşananlara şahit olan çocuk, gördüklerinden, duyduklarından etkilenir ve içinden bir şeylerin koptuğunu, üzüldüğünü hisseder. İlk tepki olarak gözleriyle babasını arar (bu bölümde çocuğun, babasının kıymetini anladığı hissedilmektedir), onu rafların önünde kitap karıştırırken bulur. Resimde arkada görülen adam olayları anlatan çocuğun babasıdır. Çocuk hemen babasının yanına gider. Babası, parası kalmadığı için beğendiği iki kitaptan birini alamayacağını söyler ve alacağı kitabı seçmek için çocuğunun fikrini sorar:

-i̇lginç bir şey mi buldun? Diye sordum.

-Evet, ama dedi, artık buna ayıracak param kalmadı. Ya bunu alabilirim, ya da daha önce seçtiğimi. Sen ne dersin? (Akal, 2003: 47).

Çocuk ve babası arasında yaşanan bu diyalog, eserde karşılaşılan iki babanın farkını ortaya koyar. Okurun karşılaştığı ikinci baba karakteri, ekonomik olarak imkânları kısıtlı olmasına karşın kitaba para ayıran, okumayı seven, okuma alışkanlığı olan bir kişidir. Ayrıca çocuğunun düşüncelerine önem vermekte ve onun fikrini almaktadır. Kısacası, otoriter değil demokratik davranan, başkalarının düşüncelerini önemseyen bu babanın çocuğunun büyüdükçe; düşünen, düşüncelerini rahatlıkla ifade eden, kendine güvenen bir insan olması beklenen bir durumdur. Yine babanın çok seviyor diye istediği her şeye sahip olmaya kalkmaması, kendi durumunu tartmadan beğendiği her şeye anında sahip olmak isteyen çocuklara bir örnektir. Onları düşünmeye sevk edecek bir davranış sergiler. Parasına göre hareket ederek kitaplardan birini seçmek istemesi, açıkça söylenmese de okuru "ayağım yorganına göre uzat"mak gerektiği sonucuna götürebilir.

Yazar diğer babanın aksine okurun karşısına olumlu özellikler taşıyan ikinci baba karakterini çıkarmıştır. Ancak eserde bu bölümde de babanın tavrının doğru olduğuna ilişkin en küçük bir ifade 
yer almaz. İki babanın tavırları karşısında okur; düşünmek, tartışmak, eleştirmek ve sonucunda bir değerlendirme yaparak doğru ve yanlış olan davranışlara, olumlu ve olumsuz örnek olan kişiye kendisi karar vermek durumunda kalır. Bu durum yazarın eleştirel ve taraflı bir anlatıma sahip olmadığının, metnin tek değil çok anlamlı olduğunun en büyük göstergesidir.

Ayrıca yazarın okurunu karşılaştırdığı bu iki aile de çocukların özellikleri benzer, babalarınki ise farklıdır. Benzer durumlarda insanların (eserde babaların) farklı tepkiler vermesi, farklı davranışlar sergilemesi aynı zamanda çocuk okur için bir hayat dersi olabilir. Çünkü bu durum insanların farklı düşüncelere sahip olabileceği, farklı şeylere değer verebileceği, herkesin "bizim gibi” olmadığı, "bizim gibi düşünmeyebileceği” vb. gerçekleri de göstermektedir. Bu yönüyle eserin okurları hayata hazırladığı da söylenebilir.

Öykünün son bölümünde çocuğun, babasının elindeki kitaplara "bir bardak su ya da çift katlı bir hamburgermiş gibi” baktığını söylemesi yine tesadüf değildir. Bu sözler daha önce karşılaşılan babanın kızına kitap yerine sunduğu seçeneği hatırlatır.

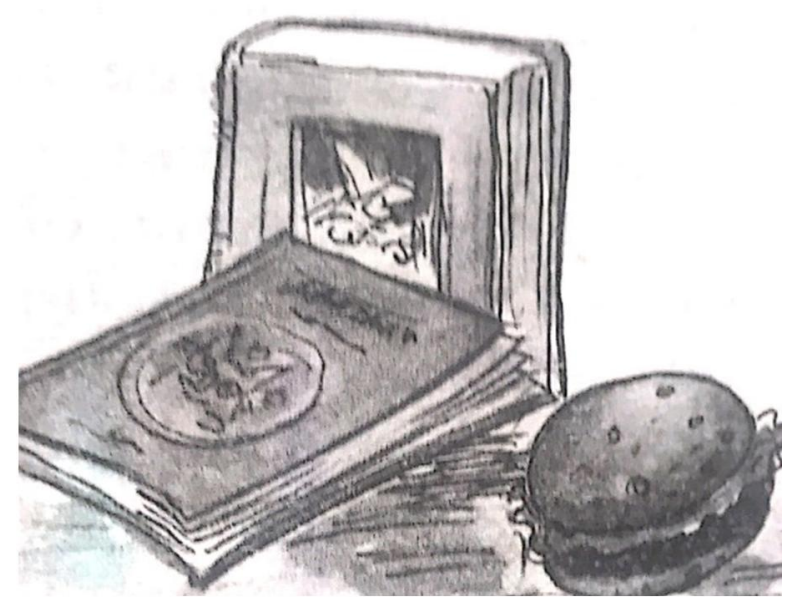

(Akal, 2003: 48)

Bu bağlamda okurun, eserde iki babanın ve çocukların özelliklerini düşünerek, yaşananları zihninde tartışarak eserin derin yapısında "kitabın aslında yemek içmek gibi temel, hayati bir ihtiyaç olduğ u" fikrine ulaşması mümkündür. Bu mesaj anlatılan olay üzerinden ulaşılabilecek bir sonuçtur ve yine öyküde bu yargıya dair açıkça söylenen bir ifade, nasihat vb. yer almamaktadır. Bu durum çocuk kitaplarında dayatmadan, okurun tartışmasını sağlayarak bir sonuca vardırma anlayışına uygun hareket edildiğini göstermektedir.

Babasının iki kitaptan birini seçmek zorunda kaldığını gören çocuğun tavrı yine okur için örnek oluşturacak türdendir.

Her olasılığa karşı her zaman yanımda bulundurduğum birikmiş harçlığımı çıkarttım, babama uzattım.

-Fazla değil ama... O kitaba yeter sanırım, dedim.

Şaşırdı, elimdeki parayı iterek geri çevirmek istedi. Ama ben kararlıydım. Parayı avucuna koydum.

-Bugüne kadar hep sen bana kitap aldın baba, dedim. Bu kez sıra bende... (Akal, 2003: 48). 
Bu ifadelerde yine bir öğüde, açıkça söylenmiş bir fikre rastlanmamaktadır. Ancak düşünüldüğünde okurun; fedakârlığın her zaman anne babadan beklenmemesi gerektiği, ihtiyaç halinde çocukların da anne babaları için fedakârlık yapmaları gerektiği gibi bir hayat dersi çıkarması ihtimal dâhilindedir. Ayrıca yazar, kahramanına bu davranışı sergileterek okurlarına karşılaştıkları sorunlar için imkânları doğrultusunda çözüm üretmeleri gerektiğini söylemek yerine bunu bir örnekle onlara göstermiş olur. Ek olarak, çocuğun "her olasılığa karşı her zaman yanında para bulundurması" tedbirli olmakla; birikmiş parasının olması tutumlulukla; parasını ihtiyacı olduğu için babasına vermesi ise paylaşmak ve yardımlaşmakla ilgilidir. Bu davranış, içerisinde pek çok değeri barındırmakta ve bu değerlerin okurların dünyasına girmesi için kapı aralamaktadır.

Kısaca bu öyküde okur, kişilerin özellikleri ve yaşanan olaylara bakarak "kimin doğru davrandığı? Kimin yanında olması gerektiği?” sorularını sorma ihtiyacı duymakta, yapılan sorgulama sonunda kendi doğrusunu bulmaktadır. Söz yerine davranışların öne çıktı̆̆ bu öykü, çocukların sözden ziyade davranışı örnek alan yapılarına uygun bir zemine sahiptir.

Yetişkinlerin de bu eseri okuduğunda kendinden bir şeyler bulması, kendini sorgulaması mümkündür. $\mathrm{Bu}$ yönüyle eser, hem çocuklara hem yetişkinlere seslenebilecek niteliktedir ki bu da yine çocuk kitaplarının taşıması gereken, çocuk kitaplarında aranan bir niteliktir.

\section{Sonuç}

Çalışmada, Aytül Akal'ın "Güzel Kitaplarım” adlı öyküsü, antiotoriter anlatım özelliği açısından incelenmiştir. Bu araştırmanın verilerine göre eserde; öğüt verme gibi öğretici amaçlara işaret eden bir yaklaşım olmadığı, eserde açıkça mesaj vermek yerine sezdirme, konu üzerinde düşündürme, keşfettirme yolunun tercih edildiği belirlenmiştir. Bu durum yazarın eserde, bir öğretmen/öğretici olarak yer almadığını ancak çocuğu düşünmeye sevk etmesi bakımından yol göstericilik işlevine sahip olduğunu ortaya koymaktadır.

Yazarın düşüncelerini okura açıkça söylemek yerine okuru gerçek hayatta karşılaşılabilecek özellikte ve de birbirinden farklı tutum ve davranışlara sahip insanlarla karşılaştırmayı tercih ettiği saptanmıştır. Bu kişilerden demokratik olma, kitap okumayı sevme gibi olumlu özelliklere sahip olanların güler yüzlü, yüz ifadesi yumuşak; otoriter/baskıcı olma gibi olumsuz özelliğe sahip kişinin sert, asık suratlı olarak resmedildiği görülmüştür. Yılmaz ve Destegüloğlu (2019: 1107) da "Çocuk Kitaplarına Yansıyan Şiddet” başlıklı çalışmalarında otoriter ve olumsuz karakterlerin sert, gergin, sabırsız, ifadesiz ve asık suratlı bir biçimde resmedildiğini belirtmektedirler. Benzer şekilde Karagöz'ün (2018: 1772 ) "Resimli Çocuk Kitaplarında Gözden Kaçan Bir Alan: İleti Problemi (Anne Tavuk Anlatıyor Serisi Örneği)" adlı araştırmasında da katılımcılar, otoriter öğretmen karakterinin fiziksel ve duygusal şiddete eğilimli bir görüntü çizdiğini belirtirler. Dolayısıyla, çalışmada otoriter karakterlere ait özellikler konusunda elde edilen verilerin, alan yazındaki farklı çalışmaların verileriyle benzerlik gösterdiği görülmektedir.

Eserde çocuk kahramanların ikisinin de olumlu özelliklere sahip olması, çocuk okur açısından bakıldığında bireylerin kendi yaşlarına yakın kişileri model alma eğilimiyle (Eyyam, Doğruer ve Meneviş, 2012: 85) de örtüşen bir özelliktir. Bu noktada kimlerin davranışının doğru, kimlerin davranışının yanlış olduğu yine eserde belirtilmemiş yaşananlar üzerinden bunun kararının verilmesi okura bırakılmıştır. Bu da yazarın okura demokratik bir ortamı sağladığını göstermektedir. Ayrıca yukarıda belirtilen özellikler, eserin okunması sırasında okurun zihinsel olarak aktif olduğunu (düşünme, tartışma, eleştirme vb.), göstermektedir. Dilidüzgün (2007: 143), Ayla Çınaroğlu'nun 
kitaplarını öğreticilik sorunu açısından değerlendirdiği çalışmasında, Çınaroğlu'nun yetişkin anlatıcıyı bütünüyle gizlediğini, çocuğun burada edilgin bir alıcı değil, etkin bir oluşturucu ve alınması gereken dersi içselleştirmiş bir özne konumunda olduğunu belirtir. Buna bağlı olarak antiotoriter anlayışın okuru aktif ve oluşturucu kıldığı sonucuna varır. Bu bakımdan iki çalışmanın sonuçları örtüşmektedir.

Eserde açık olarak işlenmiş fikirlerin olmaması, okurun kendi duygu ve düşünce dünyasına göre metni alımlamasını sağlayacağından metin, çok anlamlılık özelliği kazanmaktadır. Metnin tamamı dikkate alındığında eserin ana fikri olduğu düşünülebilecek bir ifadeye rastlanmaması, sloganı andıran yani doğru ve yanlışı gösteren cümlelerin bulunmaması, emir ve gereklilik kipinin anlatımda kullanılmaması, taraflı olunmaması gibi özellikler üzerinden, inceleme yapılan eserin antiotoriter bir anlayışla kaleme alındığı sonucuna ulaşılmıştır.

Araştırmanın bulguları; otoriter, öğretici bir yaklaşım benimsenmeden de okuru düşündürmenin, okura insan ve insanlık durumlarına ilişkin duyarlıklar, değer, tutum ve davranış kazandırmanın mümkün olduğu sonucunu ortaya koymaktadır. Bu sonucu destekleyen bir çalışma Dilidüzgün tarafından gerçekleştirilmiştir. Dilidüzgün (2007: 142) "Öğreticilik Sorunu Bakımından Ayla Çınaroğlu'nun Çocuk Kitapları” adlı çalışmasında, dayatarak değil, yaşatarak ve sonuçları hedef kitlenin çıkartmasına olanak sağlayarak yazılan kitapların çocuklara aynı zamanda eğitim de verdiğini belirtir. Böylece çocuk edebiyatı eserlerinde otoriter anlatım yerine antiotoriter bir anlayışı benimseyen edebî nitelikteki eserlerle eğiticilikten tamamen vaz geçmeden öğreticiliğin sıkıcılığı ortadan kaldırılabilecek ve çocuklara kitap sevgisi ve okuma alışkanlı̆̆g kazandırılması, okuma kültürü edindirilebilmesi daha mümkün olacaktır.

Antiotoriter anlatım özelliği, çocuk edebiyatı eserlerinde aranan "çocuğa görelik" niteliğinin değerlendirilmesinde dikkate alınan temel ilkelerden biridir. Çocuklara kitap sevgisi, okuma alışkanlığı ve kültürü kazandırılması için onlara kitap seçerken çocuğa görelik ilkesine uygun olarak hazırlanmış, nitelikli eserlerin seçilmesi büyük önem taşımaktadır.

\section{Kaynaklar}

Akal, A. (2003). Güzel Kitaplarım. Babam Duymasın. İstanbul: Uçanbalık.

Aslan, C. (2017). Örnek Eğitim Durumlarıyla Türkçe-Türk Dili ve Edebiyatı Öğretimi. Ankara: Anı.

Başaran, M. ve Altuner, G. Ş. (2016). İlkokul 4. Sınıf Öğrencilerinin Okuma Alışkanlıklarının Çeşitli Değişkenler Açısından İncelenmesi (Yozgat Örneği). 1. Uluslararası Bozok Sempozyumu $\begin{array}{llll}\text { Sempozyumu. } & \text { Sempozyum } & \text { Kitapçı̆̆ı. } & \end{array}$ https://bozoksempozyumu.bozok.edu.tr/dosya/cilt2/582-592.pdf

Canlı, S.; Doğan Güldenoğlu, B. N.; İnce Samur, A. Ö. (2016). Üç Kuşağın Yazarı: Gülten Dayığlu. Ankara: Ankara Üniversitesi Yayınları (Ankara üniversitesi Çocuk ve Gençlik Edebiyatı Uygulama ve Araştırma Merkezi).

Çocuk Vakfı (2006). Türkiye Gerçeği: Okumama Alışkanlığı. Türkiye'nin Okuma Alışkanlığı Karnesi. Çocuk Edebiyatı Okulu. http://www.cocukvakfi.org.tr/. Erişim Tarihi 20.04.2020.

Dilidüzgün, S. (1996). Çağdaş C,ocuk Yazını: Yazın Eğitimine Atılan İlk Adım. İstanbul: Yapı Kredi.

Dilidüzgün, S. (2007). Öğreticilik Sorunu Bakımından Ayla Çınaroğlu’nun Çocuk Kitapları. III. Ulusal Çocuk ve Gençlik Edebiyatı Yaşayan Yazarlar Sempozyumu Dizisi. -Çocuk ve Gençlik Edebiyatında Ayla Çınaroğlu Sempozyumu-. Eskişehir: Türkiye. 17-19 Ekim. Cilt 1. no.o. S.139145 .

Dilidüzgün, S. (2013). Ana Çizgileriyle Çocuk Ve Çocuk Edebiyatı. Okulöncesinde Çocuk Edebiyatı. Eskişehir: Anadolu Üniversitesi Yayınları. 
Durualp, E.; Çiçekoğlu, P.; Durualp, E. (2013). Sekizinci Sınıf Öğrencilerinin Kitap Okumaya Yönelik Tutumlarının İnternet ve Kitap Okuma Alışkanlıkları Açısından İncelenmesi. Uluslararası Türkçe Edebiyat Kültür Eğitim Dergisi. S. 2/1. s.115-132,

Erdoğan, F. (2019). İlk Hevesten İmza Gününe Çocuklar için Yazmak. İstanbul: Binbirkitap.

Eyyam, R.; Doğruer, N.; Meneviş, İ. (2012). Öğrenme ve Öğretme Kuramlar, Modeller, Yaklaşımlar. (Ed. Zeki Kaya). Ankara: Pegem Akademi.

İnce Samur, A. Ö. (2016). Okuma Kültürü Nasıl Kazandırılır. Okulöncesi Dönem/o-6 Yaş. Ankara: Anı.

Karagöz, B. (2018). Resimli Çocuk Kitaplarında Gözden Kaçan Bir Alan: İleti Problemi (Anne Tavuk Anlatıyor Serisi Örneği). Elektronik Sosyal Bilimler Dergisi. C. 17. S. 68. s.1765-1787

Kavcar, C. (1999). Edebiyat ve Eğitim. Ankara: Engin Yaynevi.

Lukens, R. J.; Smith, J. J.; Miller Coffel, C. (2018). Çocuk edebiyatına Eleştirel Bir Bakış. (Çev. Cenk Pamay). İstanbul: Erdem.

Nas, R. (1999). Metinlerle İlkokuma Yazma Öğretimi. Bursa: Ezgi Kitabevi.

Sever, S. (2003). Çocuk ve Edebiyat. Ankara: Kök.

Sever, S. (2015). Çocuk Edebiyatı ve Okuma Kültürü. Ankara: Tudem.

TDK (2005). Türkçe Sözlük. Ankara: Türk Dil Kurumu.

Yıldız, M.; Ketenoğlu Kayabaşı, Z. E.; Ayaz, E. ve Aklar, S. (2017). Bazı Çocukların Kitap Okumayı Sevmeme Nedenleri. JASSS (The Journal of Academic Social Science Studies). 55. p. 507-524

Yıldırım, A.; Şimşek, H. (2008). Sosyal Bilimlerde Nitel Araştırma Yöntemleri. Ankara: Seçkin.

Yılmaz, B.; Köse, E.; Korkut, Ş. (2009). Hacettepe Üniversitesi ve Bilkent Üniversitesi Öğrencilerinin Okuma Alışkanlıkları Üzerine Bir Araştırma. Türk Kütüphaneciliği 23 (1), s. 22-51

Yılmaz, O.; Destegüloğlu, B. (2019). Çocuk Kitaplarına Yansıyan Şiddet. Elementary Education Online, 18 (3). pp. 1099-1112 